\title{
Landslide Hazard Zonation Study in Eastern Indian Himalayan Region
}

\author{
Manmohan Singh Rawat ${ }^{1}$, Rajendra Dobhal ${ }^{1}$, Varun Joshi ${ }^{2}$, Yaspal Sundriyal ${ }^{3}$ \\ ${ }^{1}$ Uttarakhand State Council for Science and Technology, Vigyan Dham Jhara, Dehradun, India 248007 \\ ${ }^{2}$ Guru Govind Singh Indra Prastha University, Sector 16C, Dwaraka, New Delhi, India 110078 \\ ${ }^{3}$ Hemawati Nandan Bahuguna Garhwal University, Srinagar 246174
}

\begin{abstract}
Sikkim State in the eastern Indian Himalayan Region experiences intensive landslides because of its geologically brittle terrain coupled with heavy rainfall and anthropogenic influences. Based on satellite images and a toposheet from the Survey of India, a total of 50 landslides were identified in a study area of $133.8 \mathrm{~km}^{2}$. Among them, 43 were validated in field survey. The important factors for landslide hazard are identified and thematic maps are prepared in ArcGIS. Impacting factors including geomorphologic properties, drainage and soil conditions are assigned weight factors according to our work knowledge in this region to generate thematic layers in ArcGIS for landslide hazard analysis. A landslide hazard zonation map containing five classes, ranging from very low hazard to very high hazard, is produced. The results provide a reliable database for disaster detection and post disaster management, which is essential to planning developmental activities in this district.
\end{abstract}

Keywords: landslide inventory, morphometry, landslide hazard zonation, satellite data, thematic layers

\section{Introduction}

Hill slopes in the Himalayan region are often prone to instability due to unfavourable geological conditions, river systems with active hydraulic erosion, groundwater conditions, deforestation and other anthropogenic influences (Rawat et al 2015a). In addition, external triggering factors such as high annual precipitation and seismic activities also increase the probability of instability of hill slopes. With landslide hazards, the Himalayan region is facing major problems of environmental degradation. Therefore, all civil constructions and associated excavations should be properly planned with adequate geological and geotechnical inputs. For this purpose, there is a great need of landslide susceptibility mapping to identify potential landslide areas. Sikkim State in the eastern Indian Himalayan Region (IHR) covers an area of $7,096 \mathrm{~km}^{2}$ and bound in the south by the Great Rangit River, Chumbi valley in the east, Nepal in the west and Tibet (China) in the north (Raina and Srivastava 1992). Sikkim Himalayan region is characterized by high denudation rates, its suspended load reaches up to $500-1000$ ton $/ \mathrm{km}^{2} /$ year (Starkel and Basu 2000). Most of its rivers constantly shift channels due to suddenly high discharges during monsoon seasons (Jana 2002). The study area is in the southern part of Sikkim state.

Landslide is a common disaster in the East district of
Sikkim under influences of a variety of causative factors, including geological structures, geo-tectonic activities, changes of river regimes, high slope variation, deforestation, inappropriate land use as well as huge amount of rainfall that acts as a triggering factor. Damages caused by those frequent, sudden and unexpected landslides are enormous and becoming increasingly costly to tackle the associated problems. Various corrective and protective measures have been adopted from time to time but the frequency and magnitude of landslide occurrences have superseded the controlling measures. A partial reason is due to lack of proper understanding of individual landslide characters, mechanisms of slide initiation, as well as in-depth information of the concerned area. It is true that this type of natural disasters cannot be checked thoroughly, but proper remedial measures can reduce the magnitude of occurrences. Thus, it is the high time to prepare such a data base and detailed landslide hazard zonation map to take necessary measures to control those hazards in the study area.

\section{Materials and Methodology}

\subsection{Study Methods}

This study includes three components: map interpretation, field surveys and factor analysis. Detail steps are shown in (Figure 1).

\footnotetext{
* Corresponding Author: Manmohan Singh Rawat, email: manmohansinghrwt@gmail.com, Tel: +91 (819) 309-9178
} 


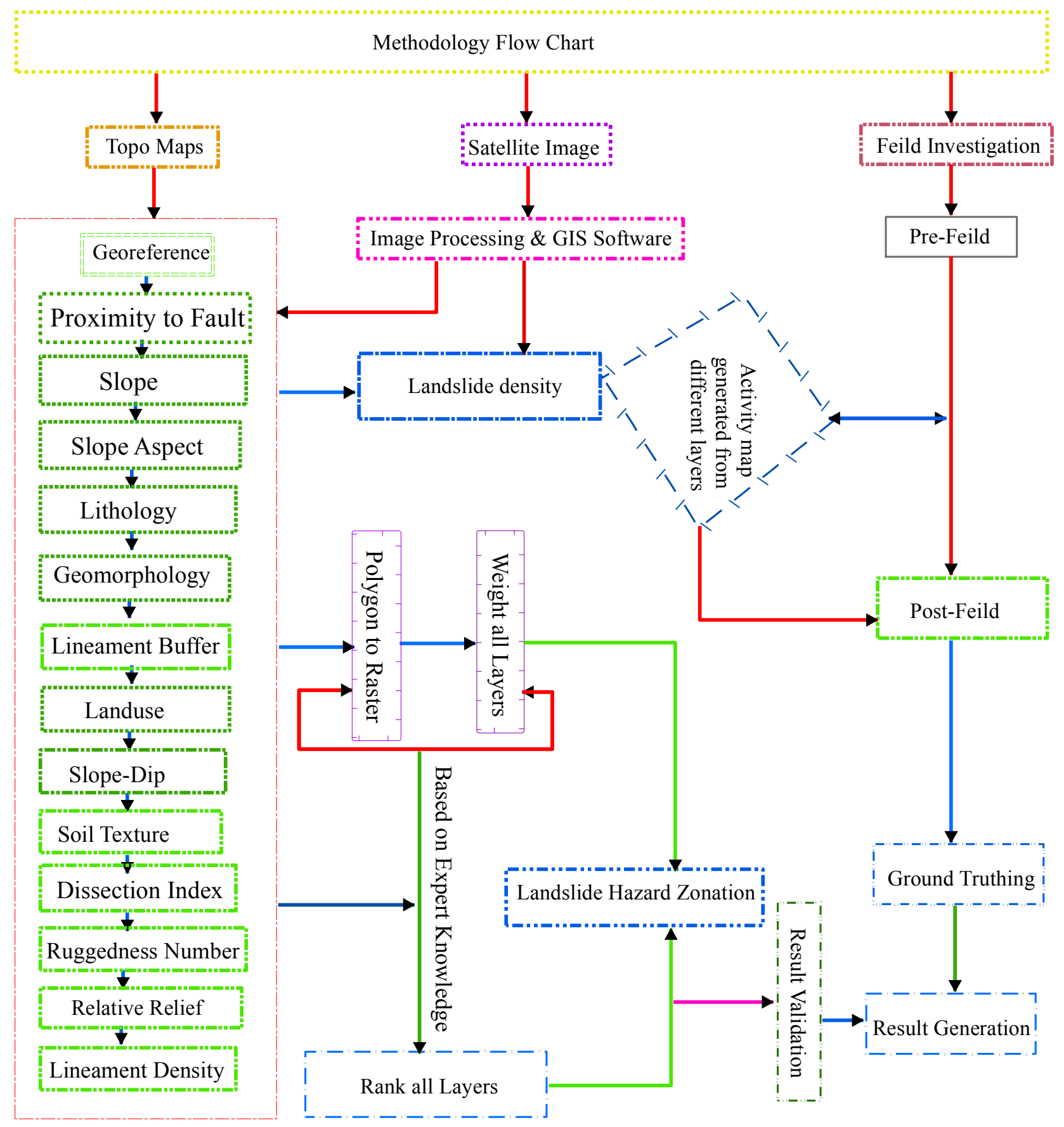

Figure 1. Flow chart depicting the methodology used in the study

\subsubsection{Geological Setting}

Sikkim State is located in the Teesta River watershed. Teesta and its tributaries erode deeply on the foothills of the Himalaya. Precambrian rocks cover a major portion of the Sikkim Himalaya and are represented by the following four major rock formations, listed from youngest to oldest: Everest Pelitic Formation, Sikkim Group, Chungthang Formation, and Kanchanjunga Gneiss Group. The central and eastern Himalaya regions near the Teesta River are characterized by large-scale thrust movements from northwest to southeast. The East Sikkim Himalaya is mainly traversed by two thrusts called the Chungthang Thrust and the Main Central Thrust (MCT), both trending in a NW-SE direction. The MCT is a well-known tectonic boundary between sedimentary and crystalline rocks, separating the Lesser and Greater Himalaya in entire Indian Himalayan Region. It is characterized by crushed rock and fracture zones. The Nepal-Sikkim Himalaya and adjacent fore deep area are dominated by conjugate strike-slip faults that face the wedges of the Indian shield. Rocks of this terrain are characterized by intense folding, metamorphism, 
and thrusting in a number of tectonostatigraphy units, which exhibit inversion in stratigraphic succession as well as in metamorphic grading. Within the study area, a total of 225 lineaments are identified from the LISS-III Satellite image (Figure 2a). Lineaments in hilly terrain indicate joints, fractures, faults and other structural features of weakness (Figure 2b) and therefore bear a direct relationship with landslides.

\subsubsection{Land use/land cover}

Land use pattern is highly controlled by the underlying lithological properties, topography and hydrology. Human settlements are mainly located in water seepage zones or near to springs. Agricultural practices are confined to areas of low relief which are underlain by weak rock formation, i.e., schists, phyllite, weathered gneisses and crushed quartzites. Forest is more frequent over moderate and steep slopes. Land use/land cover classes are classified into seven categories (Joshi et al 2001): Tree Clad area, Forest/SemiEvergreen-Dense-Open/Closed, Wasteland-Scrub landOpen scrub, Natural/Semi Natural, Agriculture land, settlements and Water bodies (Figure 3a).

Visual interpretation of Indian Satellite data was carried out at 1:50,000 scale to generate a geomorphic map (Figure 3b). Three major geomorphic units dissected hills, terraces and piedmont alluvial plains were delineated for Landslide Hazard Zonation mapping. Dissected hills cover most of the study area, $101.59 \mathrm{~km}^{2}$ out of the total of 133.8 $\mathrm{km}^{2}$. The hills are dissected by major and numerous tributaries which inflict severe erosion down hills. Alluvial fans are formed following hydraulic sediments. Elevation in this area is highly variable, ranging from $800 \mathrm{~m}$ in the south-eastern of the study area to over 4,000 m northwest.

\subsubsection{Drainage Basin Morphometry}

Drainage basin morphometry was delineated from SOI topographical map 78A/11 of the Survey of India and satellite images using Arc GIS 9.3. Morphometric analysis using the method suggested by Strahler (1956) and Goudie (1990) for the following parameters: Drainage density $(D d)$, Ruggedness Number (Rn), Dissection Index $(D i)$ and Relative Relief $(R h)$.

(1) Drainage Density

Drainage lines were digitized from Survey of India toposheet 78-A/11. Channel lengths were measured and drainage density was calculated by dividing the total channel length to catchment area. Drainage density is an important indicator of the linear scale of the landform element in stream eroded topography. A low drainage density is favoured in regions of highly permeable subsoil material, under dense vegetative cover, and where relief is low. Drainage density is also related to climate, surface roughness and runoff. Drainage density in the study area is low, varying between 1.0 to $7.5 \mathrm{~km} / \mathrm{km}^{-2}$ (Table 1, Figure $4 \mathrm{a} \& \mathrm{~b}$ ). It is classified into four classes: I, II, III and IV, denoting drainage density ranges $<3,3-5,5-7$, and $>7$ $\mathrm{km} / \mathrm{km}^{-2}$ respectively.
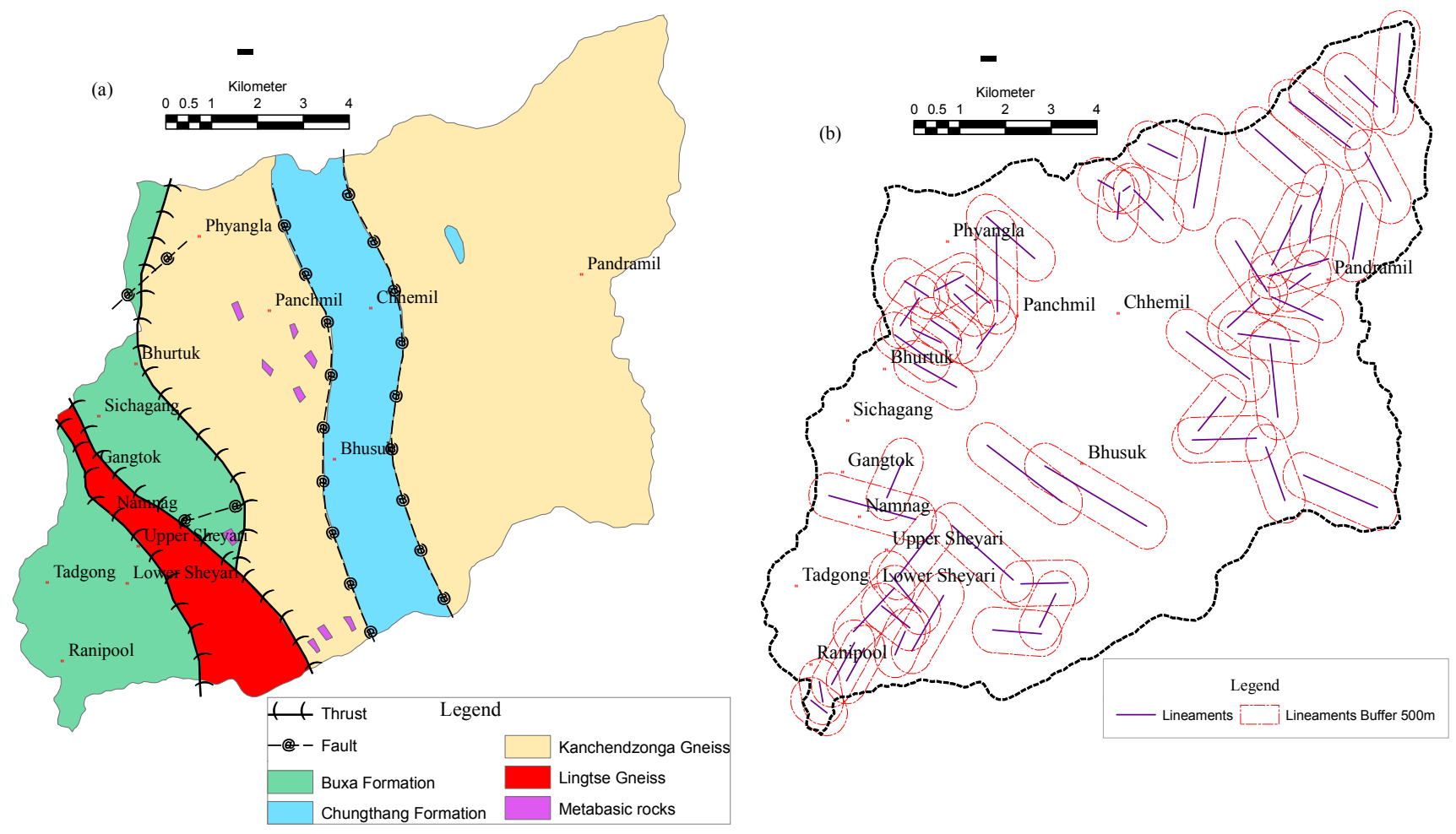

Figure 2. (a) Lithological map of the study (b) Lineament (buffer) map 

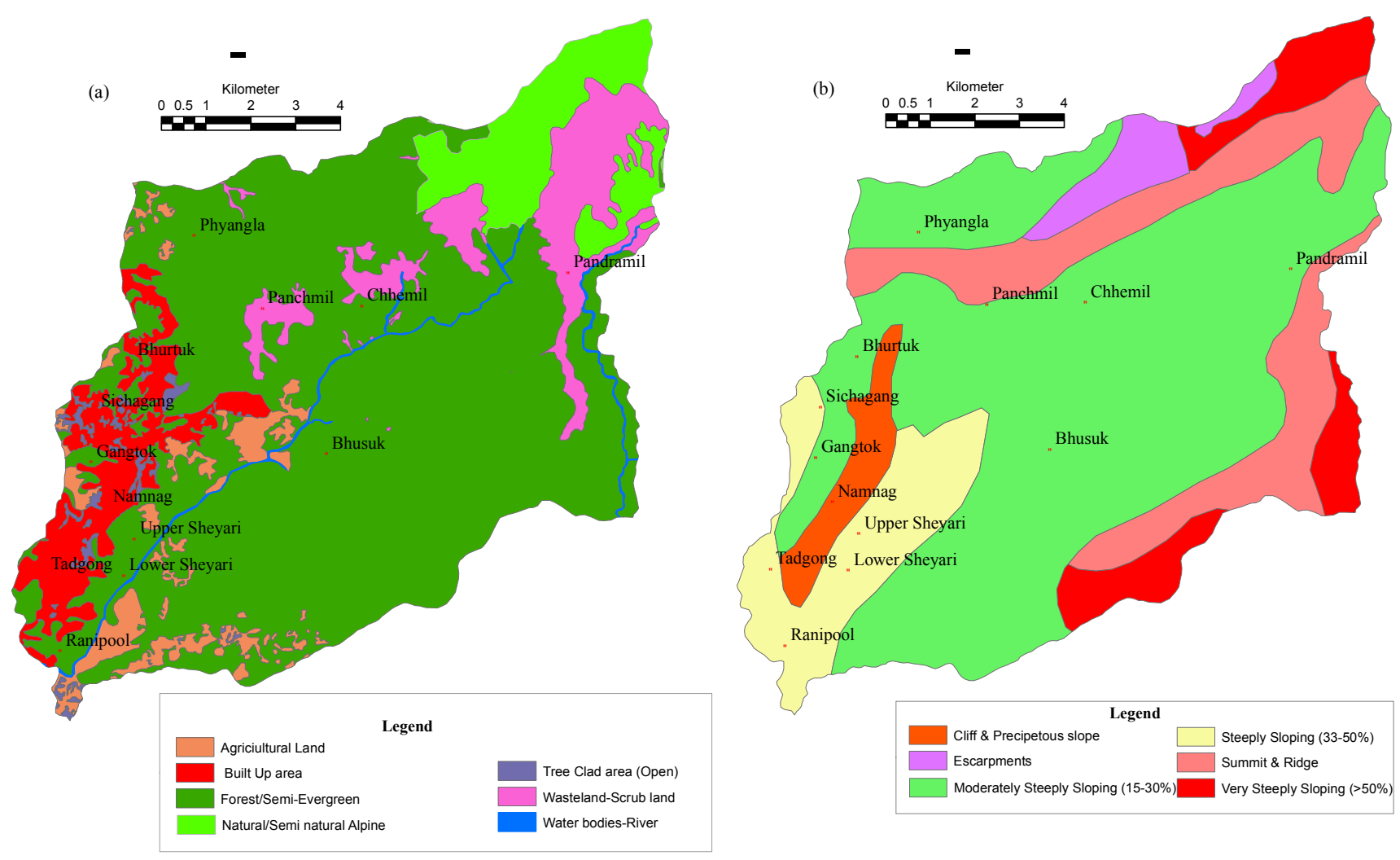

Figure 3. Land use / land cover (b) Geomorphological map of the study area
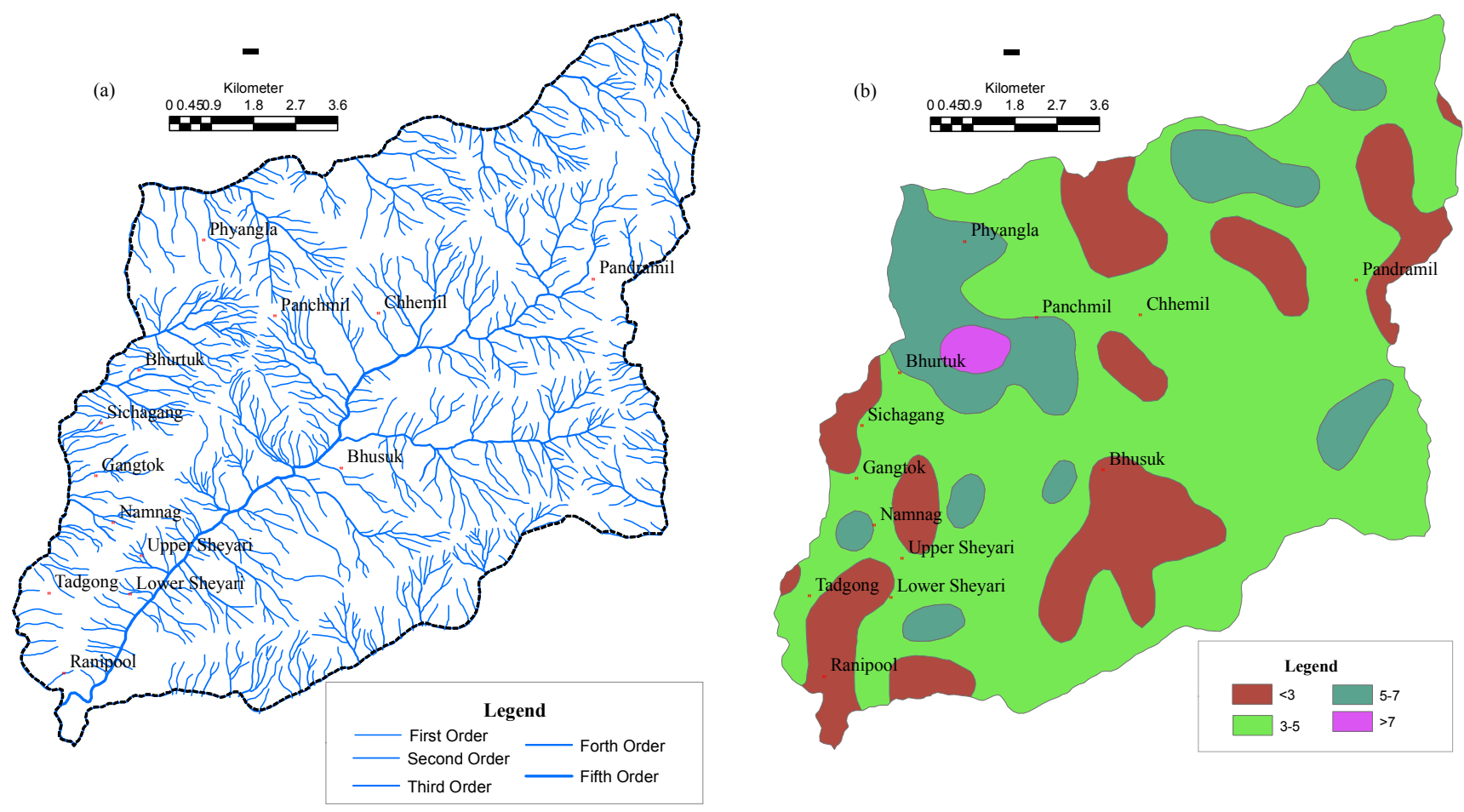

Figure 4. (a) Drainage Order (b) Drainage Density of the study area 
Table 1. Distribution of Drainage Density in the study area

\begin{tabular}{|c|c|c|c|c|}
\hline Range of Drainage Density $\left(\mathrm{km} / \mathrm{km}^{2}\right)$ & Area $\left(\mathrm{km}^{2}\right)$ & Area (\%) & Attribute & Zone \\
\hline$<3$ & 27.518 & 20.56 & Low & I \\
\hline $3-5$ & 86.797 & 64.87 & Moderate & II \\
\hline $5-7$ & 18.297 & 13.67 & Moderately High & III \\
\hline$>7$ & 1.195 & 0.89 & High & IV \\
\hline
\end{tabular}

Table 2. Distribution of Ruggedness Number in the study area

\begin{tabular}{ccccc}
\hline Ruggedness Number & Area $\left(\mathbf{k m}^{\mathbf{2}}\right)$ & Area (\%) & Attribute & Zone \\
\hline$<1250$ & 28.070 & 20.97 & Low & I \\
\hline $1251-2500$ & 70.377 & 52.59 & Moderate & II \\
\hline $2501-3750$ & 33.135 & 24.76 & Moderately High & III \\
\hline$>3750$ & 2.228 & 1.66 & High & IV \\
\hline
\end{tabular}

Table 3. Distribution of Dissection Index in the study area

\begin{tabular}{ccccc}
\hline Dissection Index & Area $\left.\mathbf{( k m}^{\mathbf{2}}\right)$ & Area (\%) & Attribute & Zone \\
\hline$<0.10$ & 4.228 & 3.16 & Low & I \\
\hline $0.11-0.20$ & 49.447 & 36.95 & Moderate & II \\
\hline $0.21-0.30$ & 69.396 & 51.86 & Moderately High & III \\
\hline$>0.31$ & 10.738 & 8.025 & High & IV \\
\hline
\end{tabular}

Table 4. Distribution of Relative Relief in the study area

\begin{tabular}{cccc}
\hline Relative Relief $(\mathbf{m})$ & Area $\mathbf{( k m}^{\mathbf{2}}$ & Area $(\mathbf{\%})$ & Attribute \\
\hline$<250$ & 5.686 & 4.25 & Low \\
\hline $251-500$ & 52.886 & 39.53 & Moderate \\
\hline $501-750$ & 70.484 & 52.67 & Moderately High \\
\hline$>750$ & 4.753 & 3.55 & High \\
\hline
\end{tabular}

\section{(2) Ruggedness Number}

Topographic Ruggedness Number $(R n)$ is the product of maximum basin relief $(H)$ and drainage density $(D d)$, where both parameters are in the same unit. An extremely high value of Ruggedness number occurs when both variables are large and slope is steep and long (Strahler 1956). Equation for the computation of Ruggedness Number is:

$$
R n=R h \times \frac{D d}{1000}
$$

where, $R n$ is ruggedness index, $R h$ is relative relief, and $D d$ is drainage density.

Ruggedness Number in the study area varies from 700 to 4,370 (Figure 5a and Table 2). They increase towards east and southwest in the study area.

\section{(3) Dissection Index}

Dissection index is the ratio of the maximum relative relief to maximum absolute relief. It reflects the dynamic potential of the area and range is from ' 0 ' (complete absence of vertical dissection) to '1' (vertical cliffs on hill slope or at sea level). The higher the dissection index is, the greater potential of the undulation and instability of the terrain. The dissection index in the study area varies from 0.01 to 0.31 (Figure $5 \mathrm{~b}$ and Table 3$)$. High dissection index $(>0.31)$ occurs in $8.025 \%$ of the total area; $3.15 \%$ of the area falls in middle to low dissection index categories and majority areas are moderately dissected.

$$
D i=\frac{R h}{R a}
$$

where, $D i$ is Dissection index, $R h$ is relative relief, and $R a$ is Absolute relief

\section{(4) Relative Relief}

Relative Relief denotes the difference between the highest and the lowest points in a spatial unit. It plays an important role to understand the morphological characteristics of the terrain, degree of dissection and denudational characteristics of the area, which together control the stream gradient, thereby influencing flood patterns (Hadley and Schumm 1961). Relative relief varies significantly in the study area (Figure 6). About $43.78 \%$ of the study area have extremely low to moderately low relative relief observed mostly in the whole southern part (Table 4). Moderate and moderately high relative relief together accounts $52.67 \%$ of the study area,

$$
R h=(H-h)
$$

where, $R h$ is relative relief, $H$ is maximum elevation, and $h$ is minimum elevation. 

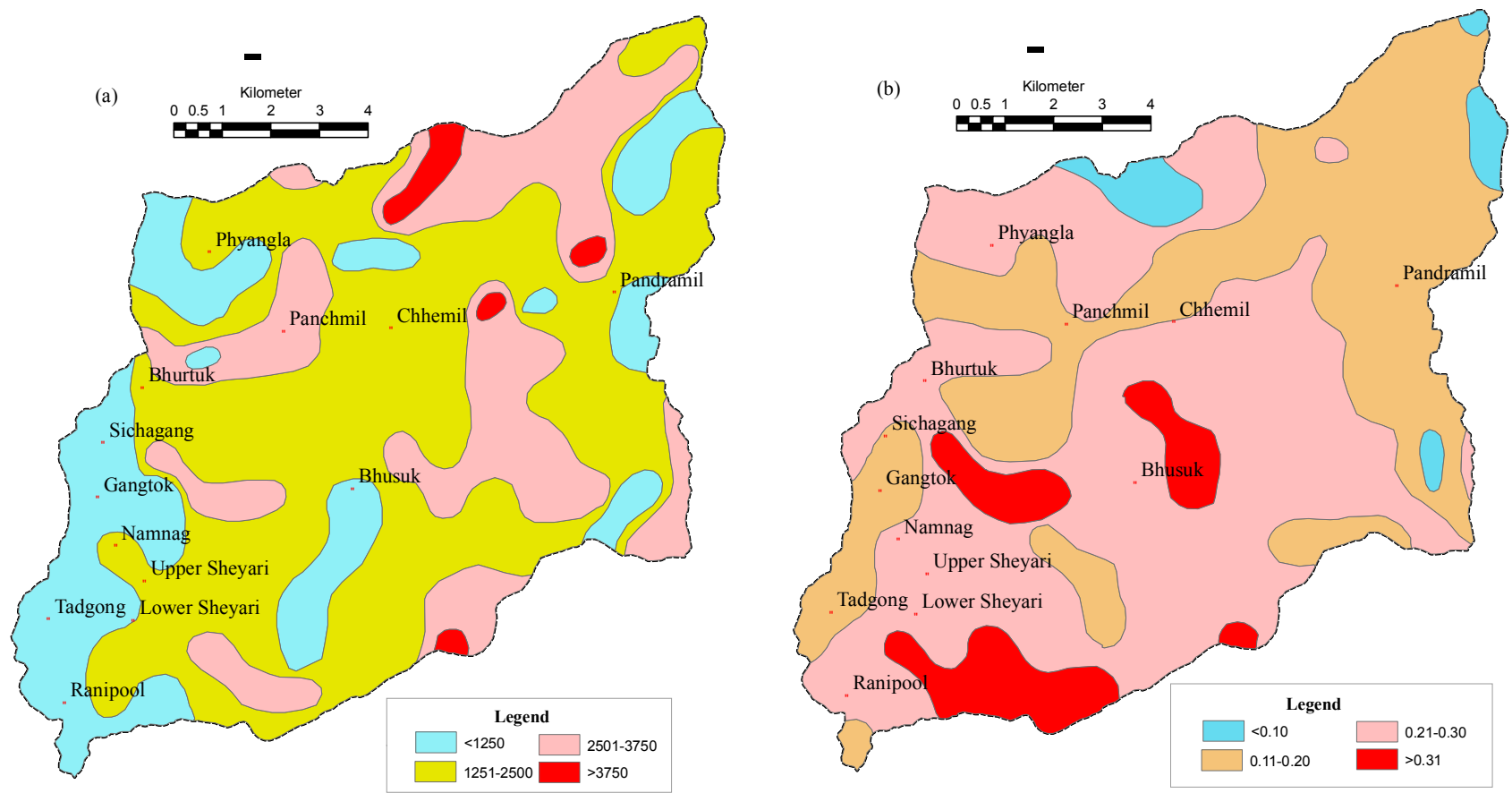

Figure 5. (a) Ruggedness number (b) Dissection Index of the study area

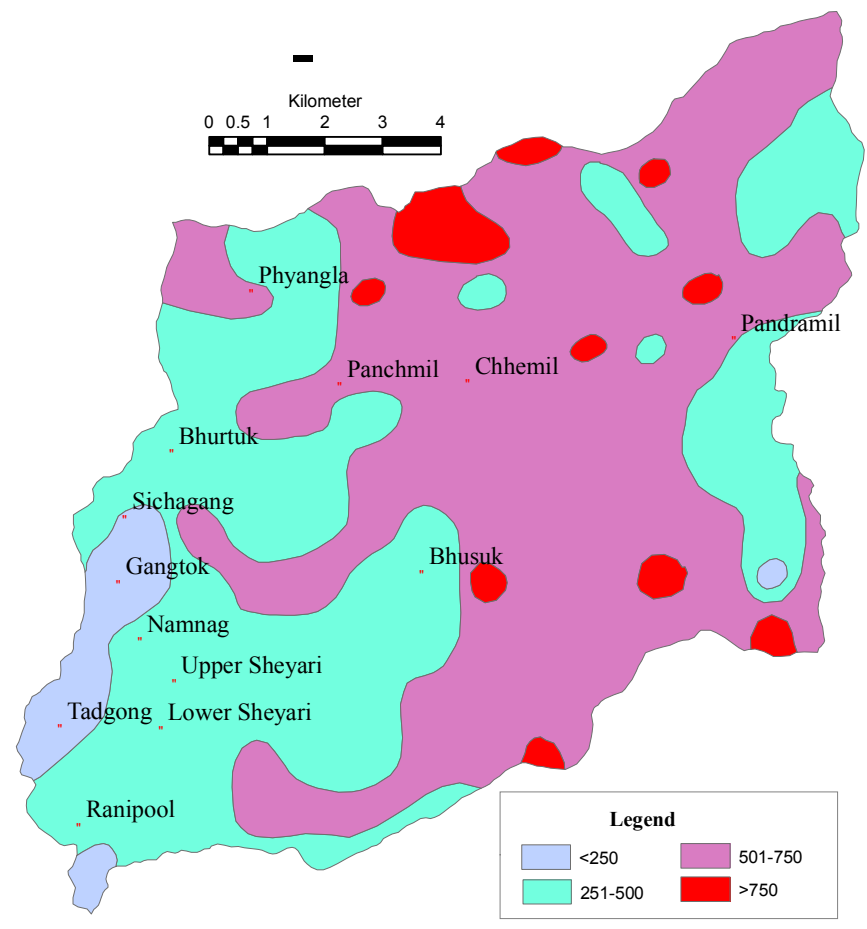

Figure 6. Relative relief of the study area

\subsubsection{Slope and Aspect}

A DEM (Digital Elevation Model) for the study area was built based on Advanced Space borne Thermal Emission and Reflection radiometer (ASTER) $(30 \mathrm{~m})$ elevation data.
GCPs were added to the ASTER imagery and processed using GIS. The most common method of landslide hazard assessment using weighted overlay, which are heavily dependent on 3-dimensional terrain visualization. Minimum 
elevation of the study area is $800 \mathrm{~m}$ and maximum elevation is 4,122 m. Digital Elevation Model was used to delineate slope in the study area. Slopes are classed to: $>15^{0}$, $15-30^{\circ}, 31-45^{0}, 46-60^{\circ}, 61-75^{\circ}$ and $>75^{\circ}$ (Figure $7 a$ ).

Landslides are more frequent in rugged areas than in gently sloping terrain. Majority landslides occur on slopes of $46^{0}-75^{\circ}$, though the highest occurrences on slopes $>75^{\circ}$. The aspect of a slope can have significant influences on microclimate. In the Himalayas, this effect can be seen to an extreme degree, south-facing slopes are warm, wet and forested, whereas north-facing slopes cold, dry and much more heavily glaciated. The aspect effect also leads to differences in hydrology and sediment transport rates. Slope aspects in the study area are divided into eight cardinal directions (Figure 7b). There is some association of landslides with slope aspect, with trend of landslides developing preferentially on Southeast to east facing slopes. Recorded landslides in these faces are SE $12 \%$, SW 20\%, NW 18\%, W 16\% and South facing 24\% in the year 1997 (Figure 7b). This is consistent with a directional trigger mechanism such as intense rainfall from tropical storm that are more frequent from ESE or SSE. Deep-seated landslides are less likely to be influenced by slope aspect, due to the over-riding controls of lithology and structure.

\subsubsection{Rainfall Effects}

Local climate varies from sub-tropical monsoon to tropical upland type, specifically the northern part of the study area features with severe winter and comparatively higher rainfall. Mean annual rainfall recorded in Gangtok station from 1995 to 2010 is $2,450 \mathrm{~mm}$. Peek rainfall occurs in monsoon season between June and September. The maximum annual rainfall occurred in Gangtok was 4,206 $\mathrm{mm}$ in the year 1996 and minimum was 2,787 mm in 2009.

Rainfall plays a vital role in landslide genesis and reactivation. An analysis of 16-year record of landslides and rainfall events in the Sikkim Himalaya suggests that many landslides occurred under the influence of extensive rainfall (reference). This study concludes that when daily rainfall amount exceeds $100 \mathrm{~mm}$, there are always risks of landslides in Himalayan slopes. It was observed that in the year of 1997, 1998, 1999 and 2000 the annual rainfall were very high during monsoon periods. These years experienced occurrences of calamitous landslides, causing serious loss of lives and properties (Rawat et al 2010).

\subsection{Major Historic Landslides}

Landslide inventory map was prepared (Figure 8) base on the Survey of India Toposheet 78A/11 (1962-63), in which 50 landslides were identified. Remote sensing data Cartosate-1 (2008), IRS 1C/1D LISS- III (2009) and LISSIV (2008) were used to validate those landslides. Of them 43 landslides were found in our field survey. Out of 43 landslides 13 were considered as significant having direct impact on roads (Supplementary pictures Plate-1-6).

\subsection{Numerical Rating Scheme}

The identification of potential landslide areas requires an integrative analysis of impacting factors according to their relative importance to landslide occurrence. This can be achieved in a rating scheme, which the impacting factors and their magnitude/classes are assigned a ranking and weight value, respectively (NRSA 2001).
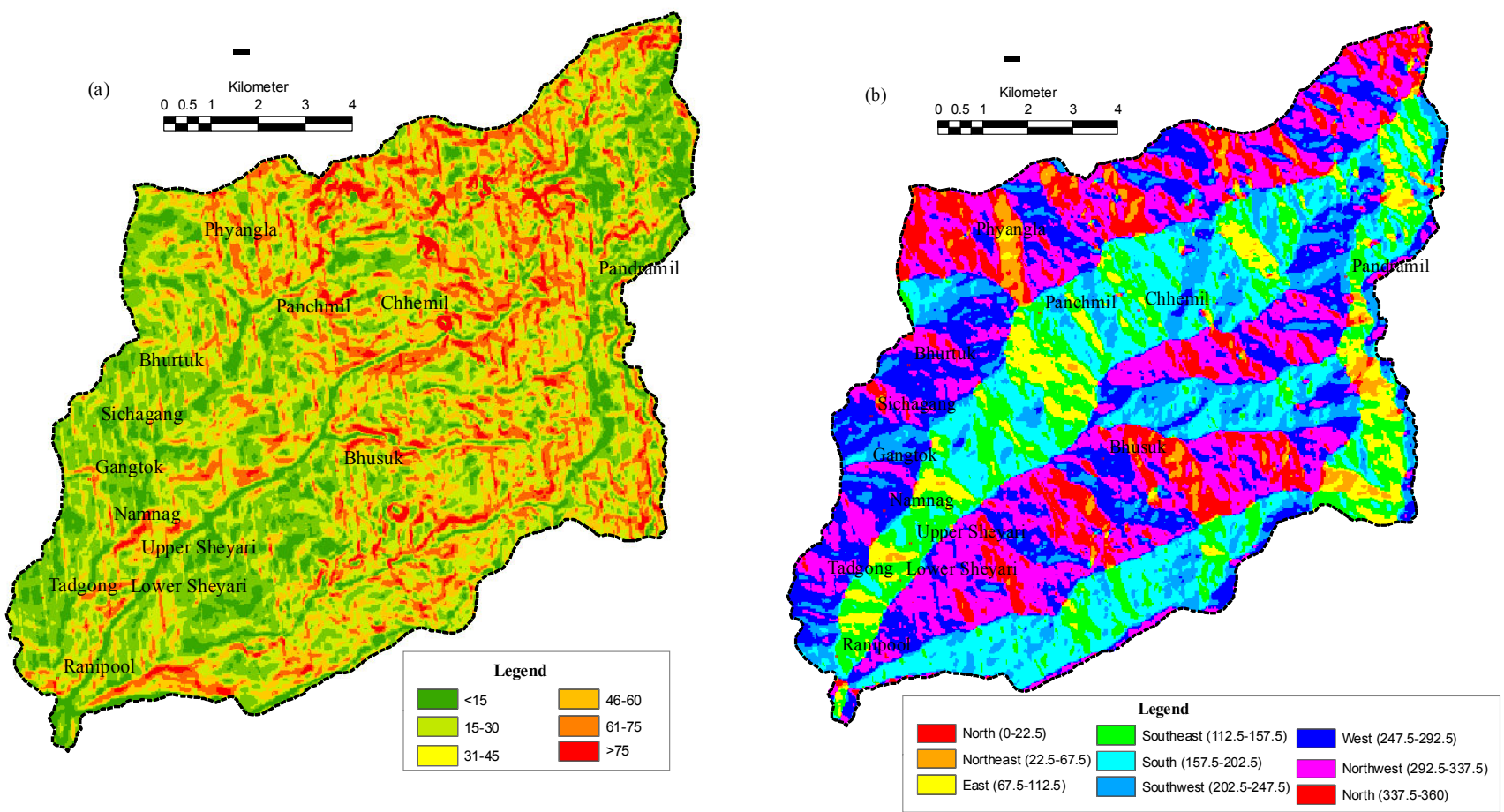

Figure 7. (a) Slope map (b) Aspect map of the study area 


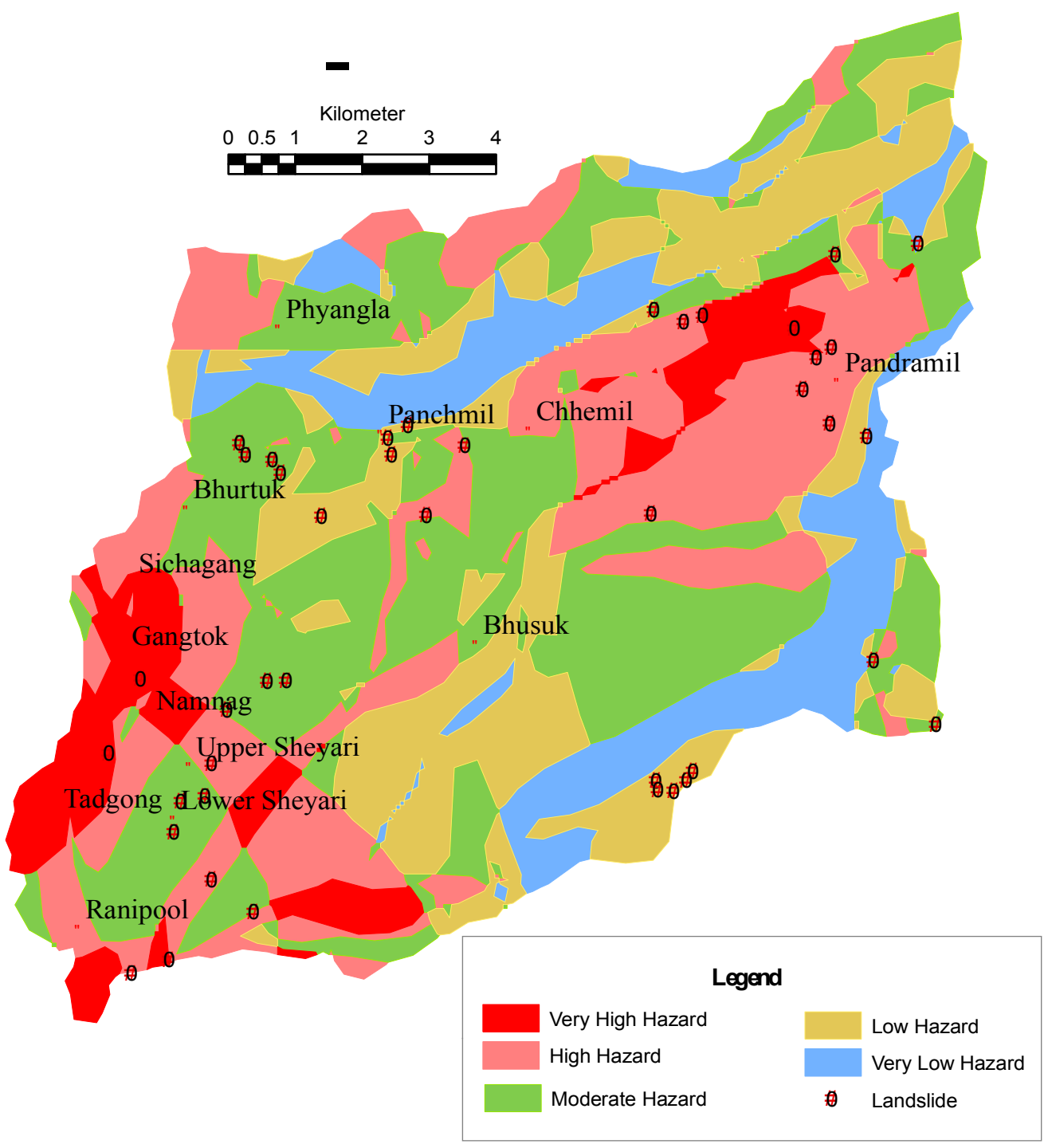

Figure 8. Landslide Hazard Zonation map of the study area

Based on our field survey and knowledge from previous work (Rawat et al 2015b), the causative factors for landslides surveyed were assigned a numerical ranking scale from 1 to 9 in an order of impacting importance. Weights were assigned to each class of these factors (Appendix Table 1). A higher value indicates more influence towards landslide occurrence.

\section{Results}

Landslide hazard zonation is categorized into five hazard classes, 'Very High', 'High', 'Moderate', 'Low' and 'Very Low'. Details of each hazard class are described as follows (Figure 8).

\subsection{Very High Hazard Zone}

Steep slopes with unconsolidated materials which are located near faults and tectonically weak zones, making this zone highly unstable and at a constant threat from landslides. This zone constitutes an area of $11.02 \mathrm{~km}^{2}$ and $13.04 \%$ of the total study area. It is mainly located in the northern and central part of the town. Because it is highly susceptible to landslides, it is recommended that no human induced activities should be undertaken in this zone. Such areas have to be entirely avoided for settlement or other developmental purposes.

\subsection{High Hazard Zone}

High Hazard Zone covers steep slopes that are prone to landslides when disturbed. It also includes areas where the probability of sliding debris is high due to weathered rock and soil debris. Several lineaments, fractured zones and fault planes also traverse the high hazard zone. Areas that experience constant erosion by streams also fall under this class. This zone is commonly found to surround the Very High Hazard Zone occupying $35.50 \mathrm{~km}^{2}$ or $26.52 \%$ of the 
total area. Since the High Hazard Zone is geologically unstable, allocation and execution of major housing structures and other projects within the vicinity of this zone should be discouraged. Also, it is recommended that proper canalization of the streams and improvement of the drainage system should be undertaken along the streams where toe-erosional activities are intense.

\subsection{Moderate Hazard Zone}

Moderate Hazard zone is generally considered stable as long as its present status is maintained. It comprises areas with a moderate slope angle and relatively compact and hard rocks. Several human settlements are found in this zone. Seismic activity and continuous heavy rainfall can reduce land stability. As such, it is important not to disturb its natural drainage. Slope alteration should also be avoided as far as possible. It is recommended that human activities that may potentially destabilize the slope and trigger landslides should not be undertaken within this zone. Although this zone comprises areas that are stable in the present condition, future land use activities have to be properly planned to maintain its status. This zone covers $42.41 \mathrm{~km}^{2}$, which is $31.68 \%$ of the total study area.

\subsection{Low Hazard Zone}

This zone comprises of areas where the impacting factors are unlikely to have adverse pressure on the slope stability. As far as the risk factor is concerned, no evidence of instability is observed within this zone, and mass movement is not expected unless major site changes occur. In addition, slope angles generally are less than 30 degree, covering with light vegetation or scrublands. It spreads over an area of $17.46 \mathrm{~km}^{2}$, or $13.04 \%$ of the total study area. This zone is suitable for development.

\subsection{Very Low Hazard Zone}

This zone includes areas of low slopes with thick vegetation. As such, it is assumed to be free from present and future landslide hazards. The dip and slope angles of bedrocks are fairly low. Although it comprises soft rocks and overlying soil debris in some areas, the chance of slope failure is minimized by low slope angle. This zone extends over an area of $27.48 \mathrm{~km}^{2}$ or $20.52 \%$ of the total area.

\section{Discussion}

Geomorphic factors such as geology and relief factors have a major control on landslide processes in this region given that slope, slope shape, aspect and lithology are proven to be the major contributing factors to landslides. Areas most sensitive to landslides are slopes at an angle between $46^{\circ}$ and $75^{\circ}$.

The output zonation map divides the study area into five hazard zones. The High Hazard Zone is in geologically unstable area, and slope failure can be triggered particularly in this zone after heavy rain. The results are validated by landslide distribution in the area during field study. As such, allocation and execution of major housing construction and other projects within this zone should be discouraged.
Afforestation scheme should be implemented in this zone. Further, future land use activities have to be properly planned to maintain its present status.

The results obtained from the study show a positive relationship between landslides and drainage density, which may be due to higher surface runoff and concomitant weather and erosion. Rock types like phyllite and gneiss with high drainage density are more prone to land sliding. Higher landslide frequency also corresponds to high lineament density, indicating that the areas with high dissection are more susceptible to landslides. The maximum landslide frequency within a range of $100 \mathrm{~m}$ distance from the road corroborates the fact that road construction is one of the prominent anthropogenic activities leading to the occurrence of landslides.

Nevertheless, landslides in this area are likely to continue increasing when local population are growing, so does the demand for lands. Settlements will continually expand into areas prone to landslide hazards. According to an open-ended questionnaire assessing local residents' understanding of the main causes of landslides, it listed steep slopes, slope shape and continuous rainfall as the major factors (Karmakar 2016). This is consistent with our findings in this study. A good understanding and perceptions of local people on landslides are important to maintain land stability and eliminate potential landslides.

The methodology for landslide hazard zonation mapping presented here involves thematic data layers generation, spatial data integration, numerical rating scheme design and results validation. The merging of multispectral and panchromatic satellite data greatly improved the understanding of terrain features in the images. The numerical rating scheme allows an improved evaluation. However, because the landslide contributing factors vary from region to region, this rating may not be hold for other regions in the Himalaya.

\section{Acknowledgement}

The authors wish to thank the local people of Sikkim for sharing their wisdoms with us during this research. We also thank reviewers for their insightful inputs.

\section{References}

Goudie, A., 1990. Geomorphological techniques. Unwin Hyman (Pub.) Ltd., Boston, 570.

Hadley, R.F., and S.A. Schumm, 1961. Sediment Sources and Drainage Basin Characteristics in Upper Cheyenne River Basin. USGS Water-Supply Paper, 1531-B, 198.

Jana, M.M., 2002. Application of remote sensing in the study of geomorphic processes and landforms in piedmont zone of Darjeeling Sub-Himalaya. Journal of the Indian Society of Remote Sensing, 30(1-2): 61 - 72.

Joshi, V., A. Naithani and G.C.S. Negi, 2001. Study of landslides in Mandakini river valley, GanhwalHimalaya, India. Gaia Lisbon, 16: 87 - 95.

Karmakar, M., 2016. Landslide hazard in Darjeeling Himalayan Region and its management: a study of 
geographical perspective. IJHMS, 2(4): 123 - 130.

NRSA, 2001. Landslide Hazard Zonation Mapping in the Himalayas of Uttaranchal and Himachal Pradesh States Using Remote Sensing and GIS Techniques. ATLAS 2001, National Remote Sensing Agency, Hyderabad.

Rawat, M.S., V. Joshi, A.K. Sharma, K. Kumar and Y.P. Sundriyal. 2010. Study of landslides in parts of Sikkim Himalaya. Indian Landslides, 3(2): 47 - 54.

Rawat, M.S., V. Joshi, D.P. Uniyal and B.S. Rawat, $2015 \mathrm{a}$. Investigation of hill slope stability and mitigation measures in Sikkim Himalaya. Intl. J. Lsld. Env., 3(1-3): $8-15$.
Rawat, M.S., D.P. Uniyal, R. Dobhal, V. Joshi, B.S. Rawat, A. Bartwal, D. Singh and A. Aswal, 2015b. Study of landslide hazard zonation in Mandakini valley, Rudraprayag district of Uttarakhand using remote sensing \& GIS. Curr. Sci., 109(1): 158 - 170.

Starkel, L. and S.R. Basun (Ed.), 2000. Rains, landslides and floods in the Darjeeling Himalaya. Indian National Science Academy, New Delhi, 168p.

Strahler, A.N., 1956. Quantitative slope analysis. Bull. Geol. Societ. Am., 67: 71 - 596.

\section{Supplementary Pictures:}

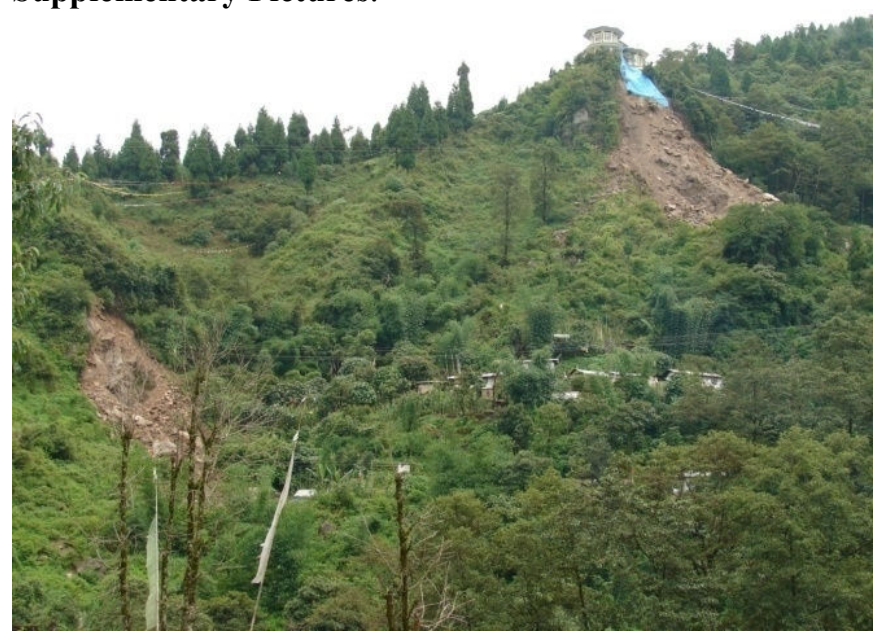

Plate 1. Chandmari slide along Gangtok-Nathula road

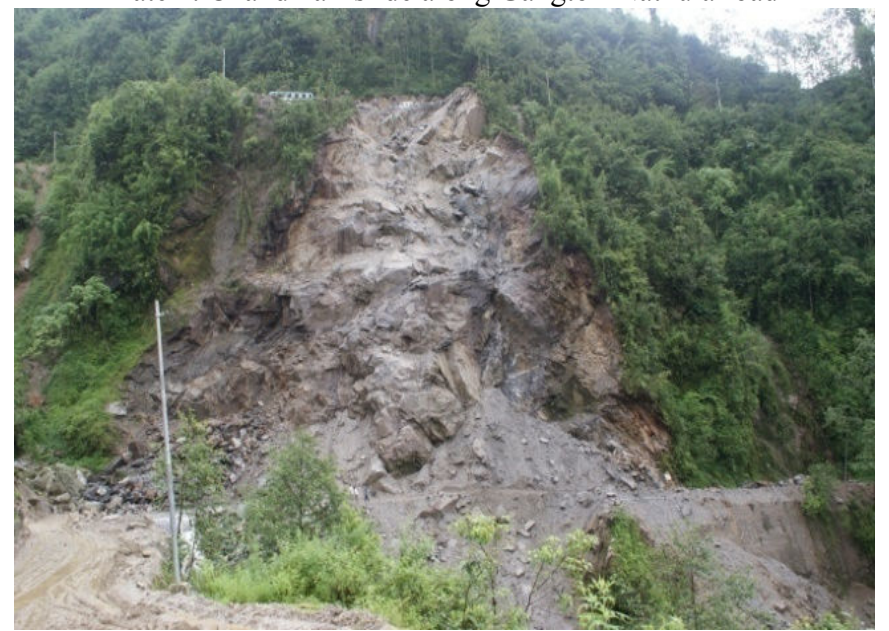

Plate 3. Bakthang slide in $\mathrm{JN}$ road

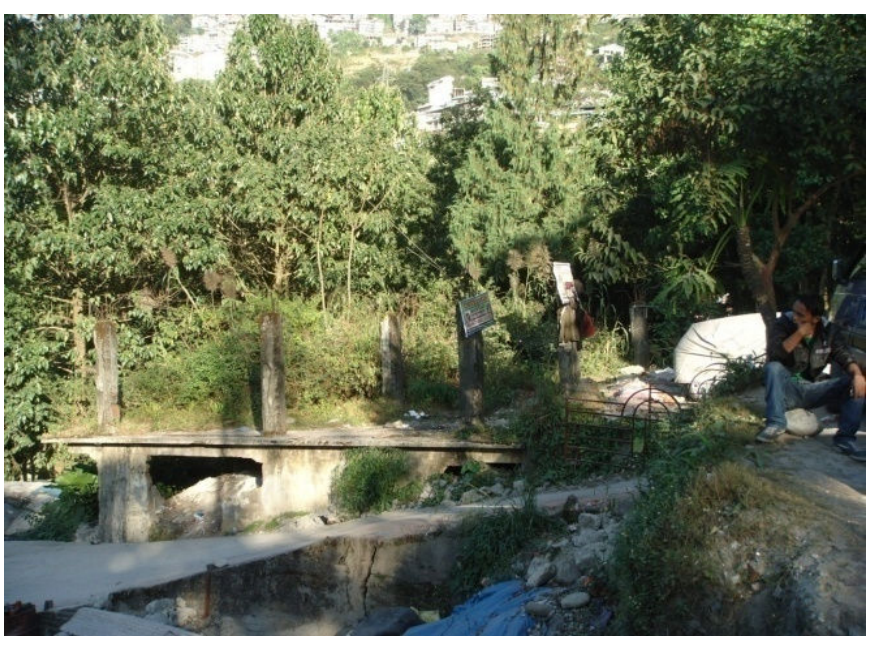

Plate 2. 6th Mile Slide along NH 31-A

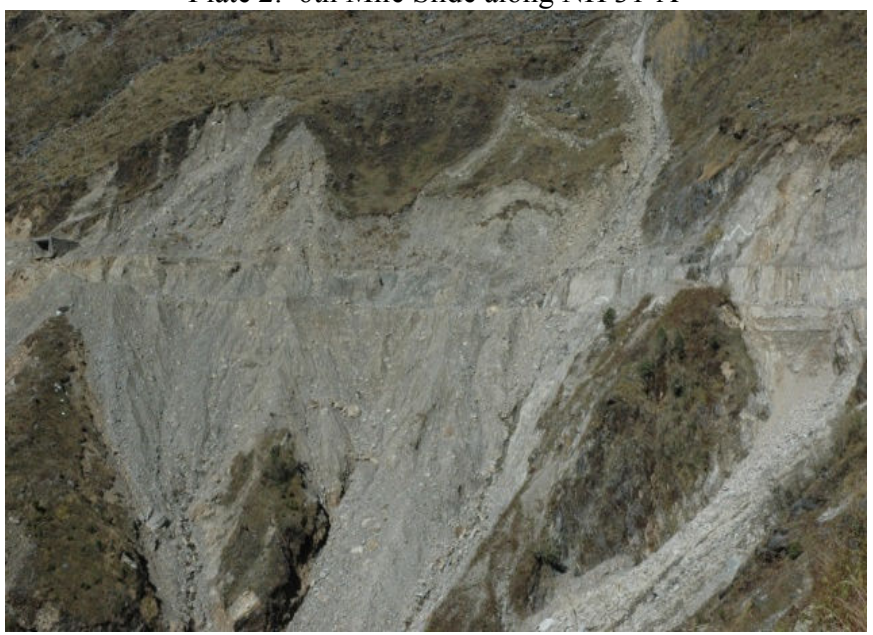

Plate 4. Andha bridge slide along Gangtok-Nathula road (2007) 


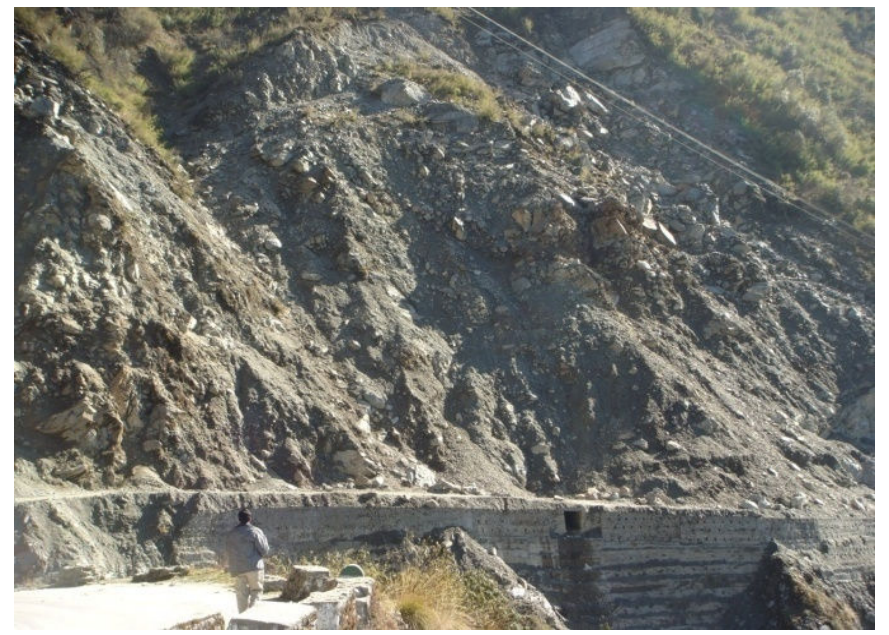

Plate 5. Kyangnosala slide along Gangtok-Nathula road

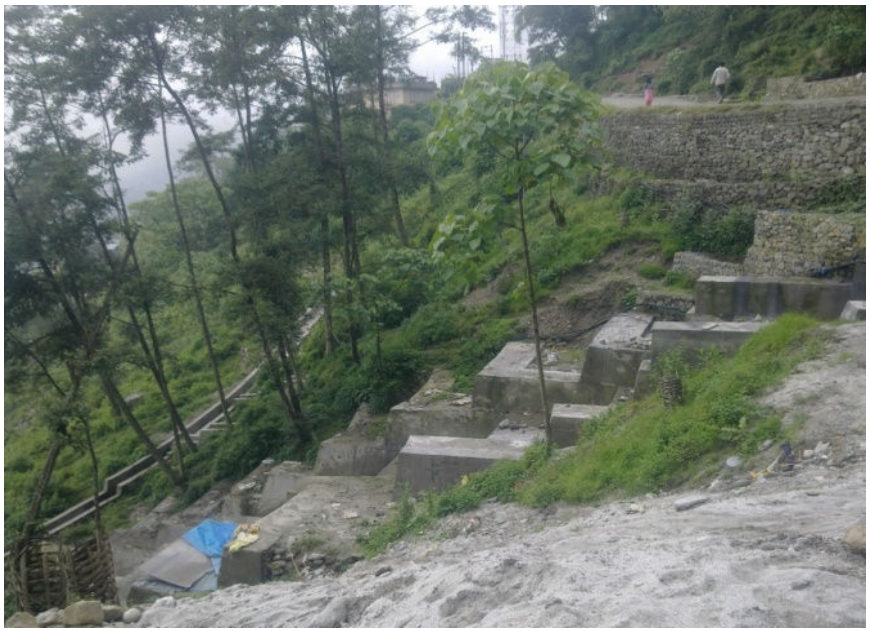

Plate 6. Manbir colony slide along By-pass road

\section{Appendix}

Table 1: Ranks and weights of thematic layers used in zonation analysis

\begin{tabular}{|c|c|c|c|}
\hline Parameter & Rank & Category & Weight \\
\hline $\begin{array}{l}\text { Proximity to fault(Length } \\
\text { Buffer distance on either } \\
\text { side) }\end{array}$ & 10 & $\begin{array}{l}\text { Major fault } 0-500 \mathrm{~m} \\
\text { Thrust } \quad 0-500 \mathrm{~m}\end{array}$ & $\begin{array}{c}8 \\
10\end{array}$ \\
\hline Slope & 9.5 & $\begin{array}{l}0-16^{0} \\
16-25^{0} \\
25-33^{0} \\
33-42^{0} \\
42-79^{0}\end{array}$ & $\begin{array}{l}1 \\
7 \\
9 \\
6 \\
5\end{array}$ \\
\hline Lithology & 9.3 & $\begin{array}{l}\text { Phyllite/Quartzite } \\
\text { Quartzite alternating with Shale/Slate/Phyllite } \\
\text { Quartzite alternating with Schist } \\
\text { Schist } \\
\text { Schist with Slate/Phyllite } \\
\text { Granites } \\
\text { Gneiss } \\
\text { Basic/Metabasic/Ulterabasic } \\
\text { Volcanics/Meta volcanic } \\
\text { Semi-consolidated sediments }\end{array}$ & $\begin{array}{l}10 \\
6 \\
7 \\
8 \\
2 \\
2 \\
3 \\
3 \\
9 \\
7 \\
\end{array}$ \\
\hline $\begin{array}{l}\text { Slope-Dip (Bedding, joint) } \\
\text { Relation }\end{array}$ & 9 & $\begin{array}{l}\text { Dip facets parallel to slope } \\
\text { Dip facets opposite to slope }\end{array}$ & $\begin{array}{c}10 \\
1 \\
\end{array}$ \\
\hline Geomorphology & 8.5 & $\begin{array}{l}\text { Low dissected hills and valleys } \\
\text { Moderately dissected hills and valleys } \\
\text { Highly dissected hills and valleys } \\
\text { Alluvial fans } \\
\text { River terraces } \\
\text { Valley } \\
\text { Escarpment } \\
\text { Toe removal /erosion/cutting(by river) }\end{array}$ & $\begin{array}{c}3 \\
6 \\
8.5 \\
4 \\
1 \\
1 \\
5 \\
9 \\
\end{array}$ \\
\hline Density of Lineament & 8 & $\begin{array}{l}\text { Low } \\
\text { Moderate } \\
\text { Moderately high } \\
\text { High }\end{array}$ & $\begin{array}{l}1 \\
3 \\
8 \\
9\end{array}$ \\
\hline Drainage Density & 7.5 & $\begin{array}{l}\text { Low } \\
\text { Moderate } \\
\text { Moderately high } \\
\end{array}$ & $\begin{array}{l}2 \\
3 \\
6\end{array}$ \\
\hline
\end{tabular}




\begin{tabular}{|c|c|c|c|}
\hline & & High & 10 \\
\hline Lineament Buffer & 7.2 & $500 \mathrm{~m}$ buffer & 10 \\
\hline Land use/land cover & 7 & $\begin{array}{l}\text { Dense vegetation ( }>40 \% \text { canopy cover }) \\
\text { Medium vegetation }(10-40 \% \text { canopy cover }) \\
\text { Degraded vegetation }(<10 \% \text { canopy cover) } \\
\text { Scrub sand/grass sand } \\
\text { Forest blank } \\
\text { Barren land (rocky) } \\
\text { Waste land } \\
\text { Agricultural land } \\
\text { Built-up area } \\
\text { Snow covered area }\end{array}$ & $\begin{array}{c}1 \\
4 \\
7 \\
6 \\
7.5 \\
8 \\
9 \\
2 \\
5 \\
3\end{array}$ \\
\hline Dissection Index & 6 & $\begin{array}{l}\text { Low } \\
\text { Moderate } \\
\text { Moderately high } \\
\text { High } \\
\end{array}$ & $\begin{array}{l}1 \\
4 \\
8 \\
9\end{array}$ \\
\hline Ruggedness Number & 5.5 & $\begin{array}{l}\text { Low } \\
\text { Moderate } \\
\text { Moderately high } \\
\text { High } \\
\end{array}$ & $\begin{array}{l}1 \\
2 \\
5 \\
9\end{array}$ \\
\hline Relative Relief & 3 & $\begin{array}{l}\text { Low } \\
\text { Moderate } \\
\text { Moderately high } \\
\text { High }\end{array}$ & $\begin{array}{l}1 \\
3 \\
6 \\
9 \\
\end{array}$ \\
\hline Soil Texture & 4.5 & $\begin{array}{l}\text { Sandy skeletal soil } \\
\text { Loamy skeletal soil } \\
\text { Sandy soil } \\
\text { Silty soil } \\
\text { Clayey soil } \\
\text { Loamy soil } \\
\text { Rock outcrop }\end{array}$ & $\begin{array}{c}1 \\
2 \\
2.5 \\
7 \\
10 \\
4 \\
1\end{array}$ \\
\hline Slope Aspects & 4 & $\begin{array}{l}\text { North (337.5-22.5) } \\
\text { NE (22.5-67.5) } \\
\text { East }(67.5-112.5) \\
\text { SE }(112.5-157.5) \\
\text { South }(157.5-202.5) \\
\text { SW }(202.5-247.5) \\
\text { West }(247.5-292.5) \\
\text { NW }(292.5-337.5) \\
\end{array}$ & $\begin{array}{c}1 \\
3 \\
5 \\
6 \\
10 \\
4 \\
2 \\
2 \\
\end{array}$ \\
\hline
\end{tabular}

